\title{
Energy pay-back time analysis of solar energy systems; pho- tovoltaics and solar collectors
}

Rand Askar ${ }^{1}$; Luis Bragança ${ }^{2}$

\section{Resumen:}

Las tecnologias de energía solar se están considerando cada vez más en el suministro de soluciones energéticas eficientes para una amplia variedad de aplicaciones para generar electricidad y calor. Se registraron altas tasas de recompensa en diferentes niveles para ambos sistemas de energía solar; Sistemas solares térmicos (ST) y fotovoltaicos $(F V)$. La explotación de la energía solar depende de la disponibilidad de recursos y las condiciones locales en cada región. Por lo tanto, este documento presenta un estudio realizado en la ciudad de Guimarães, en el norte de Portugal. Su objetivo es evaluar la eficiencia energética de varios tipos de ambos sistemas FV y ST existentes en el mercado.

El estudio realiza un análisis comparativo tanto de los módulos fotovol- taicos como de los colectores solares térmicos, como sistemas que normalmente se implementan para generar energia eléctrica y agua caliente sanitaria, respectivamente, a una escala doméstica. La energia incorporada en ambos sistemas y sus componentes se estimará basándose a la revisión literaria y siguiendo el modelo "de la cuna a la puerta" que considera las fases del ciclo de vida durante el proceso de fabricación. La energía producida por cada uno de los sistemas se estimará en este estudio utilizando el software de simulación portugués SCE.ER. Los resultados muestran los valores estimados del tiempo de recuperación de energía de cada uno de los sistemas examinados de los colectores solares y fotovoltaicos.

Palabras claves: energía fotovoltaica, calentador solar térmico, energía incorporada, energía producida, tiempo de recuperación de energía (EPBT).

\footnotetext{
${ }^{1}$ University of Minho, Department of Civil Engineering, Guimarães, Portugal - rand.askar@hotmail.com

${ }^{2}$ University of Minho, Department of Civil Engineering, Guimarães, Portugal - braganca@civil.uminho.pt
} 
Abstract:

Solar energy technologies are increasingly being considered in providing efficient energy solutions for a wide variety of applications to generate electricity and heat. High rewarding rates at different levels were registered for both solar energy systems; solar thermal systems (ST) and photovoltaics (PV). The exploitation of the solar energy is dependent on the resource availability and local conditions in each region. Therefore, this paper presents a study conducted in the city of Guimarães in north Portugal. It aims at evaluating the energy efficiency of various types of both PV and ST systems existing in the market.

The study carries out a comparative analysis of both photovoltaic modules and solar thermal collectors, as systems that are usually implemented to cogenerate the energy demand for electricity and sanitary hot water respectively at a domestic scale. The embodied energy in both systems and their components will be estimated basing on literature review and following the model "from cradle to gate" that considers the life-cycle phases during the manufacturing process. The produced energy by each of the systems will be estimated in this study using the simulation Portuguese software SCE.ER. The results show the estimated values of energy pay-back time of each of the examined photovoltaics and solar collectors systems.

Keywords: photovoltaics, solar ther- mal heater, embodied energy, produced energy, energy pay-back time (EPBT).

\section{Introduction}

Renewable energy sources are increasingly becoming considered to substitute the conventional fossil fuel energy due to their sustainability and reliability. The worldwide concerns about global warming, climate change and other serious environmental problems resulted from the burning of the fossil fuel also led to seek other renewable energy supply alternatives to create a better and cleaner living environment, thus, responding to the increased need for energy resulted from the population growth and economic development. Consequently, the development of renewable technologies is an urgent need to cope with the challenges of environmental pollution and security of energy supply [1], [2]. However, the spread of renewable technologies regarding both residential and industrial levels is dependent on their resources availability, reference market and national conditions of a certain region [3].

Due to Europe's energy dependency, the European union recognises the reduction in energy consumption and carbon emissions as important targets to mitigate the climate change and decrease the energy costs. However, the use of renewable energy sources is essential to achieve these goals [4]. In this context, until 2030 the EU framework on climate and energy carried out to reducing EU domestic carbon 
emissions by $40 \%$ and energy consumption by $25 \%$ comparing to their respective levels of 1990 [5].

The abundance of the solar energy is an important factor in its adoptions to meet the global energy demand [6]. The efficiency of the solar system is largely dependent on the geographical location in which they are installed. Therefore, studies should be conducted considering various countries with various locations to examine and compare the systems behaviour. Solar energy technologies; photovoltaics (PV) and solar thermal systems (ST) have witnessed a fast growing interest as they play an important role in exploiting the solar renewable energy. They have great potential in reducing energy consumption in building sector, backing the shift towards Nearly Zero Energy Building (NZEB).

\section{Solar energy systems}

Two types of solar systems; solar thermal systems and photovoltaics (PV).

- Solar thermal systems: in these systems, the solar energy is converted into thermal energy by direct absorption or through concentrators [7]. The thermal energy produced by such systems can be used for various industrial and residential applications such as water heating, space heating, cooking, drying and water purification, etc. Various types of solar thermal collectors are existed in the market including flat plate collectors (FPC), unglazed, evacuated tube and concentrating systems.
Photovoltaics is a rapid growing market, it has witnessed a boom over the last decade [8]. Thus, it is important to understand the energy performance of these technologies.

- Photovoltaics: these systems convert the solar energy into electricity using PV cell [7]. A PV system is composed of the PV module and the balance of system (BOS) components. Several types of modules exist in the market including crystalline silicon modules; Mono-Si, Poly-Si and thin film modules; amorphous silicon (a-Si), Cadmium telluride (CdTe) and Copper Indium Gallium Selenide (CIGS), ...etc. However, crystalline based PV systems are most utilized at the domestic level of which they represent approximately $85-90 \%$ of the global PV market [9].

\section{Materials and method \\ Solar systems specifications}

The main objective of this study is to potentially evaluate and compare the energy performance of several solar energy systems that provide two types of energy: thermal energy and electricity. Both thermal and PV systems are usually used to partially cover the energy demand at a domestic scale, thus, all the produced energy can be used effectively and can substitute the conventional energy.

The study considers a review of four common Photovoltaic systems and solar thermal heater for sanitary hot water. It summarizes the energy performance of 
two prominent crystalline based PV modules; Mono-Si, Poly-Si along with two thin film modules; a-Si and CdTe PV systems coupled with flat plate solar thermal collector FPC for sanitary hot water.

A life span of 30 years has been chosen for all the systems, and the city of Guimaraes in north Portugal has been taken as the reference geographical area where the systems were considered to mounted on a slanted rooftop. The study was carried out referring to a functional unit of one square meter of each of the systems.

The whole life cycle of solar system from cradle to grave normally consists of the phases of raw materials extraction, manufacturing process, transport, installation, operation maintenance and end of life management (dismantling, recycling and final disposal) [3].

The study assumes the life cycle of the five solar systems following the model "from cradle to gate" which considers the whole production process of the systems begins at materials extraction, manufacturing, assembly and production.

System boundary "from cradle to gate" analytical approach was chosen for this study because of the limited data available for allocation, transportation, operation, maintenance and end of life management. However, several studies report that the stages of transportation and end of life management do not have a considerable contribution to the life cycle energy demand [10], [11].

The investigated solar thermal collector is a passive solar device with natural circulation as a recommended installation for domestic use to provide a medium -low demand of sanitary hot water. It consists of three main components; the absorbing collector, the water tank and the external support and can be directly installed on slanted-roofs [12]. The total ne surface of the collector is $2.13 \mathrm{~m} 2$ which is usually required to meet the needs of a family of four members [3].

The analysed PV systems in this study consist of module and BOS components; inverter, cabling and supporting structure. Four types of PV systems were considered: Mono-Si, Poly-Si, a-Si and CdTe. An area of $20 \mathrm{~m} 2$ is usually necessary to cover the average requirements of electricity [3]. The PV modules and system efficiencies that were used in the simulation are presented in table (1):

Table 1: PV modules and systems efficiency

\begin{tabular}{lcccc}
\hline Module type & Mono-Si & Poly-Si & a-Si & \multicolumn{2}{c}{ CdTe } \\
\hline Module Efficiency \% & 12 & 11 & 6 & 8 \\
\hline Performance ratio \% & 85 & 85 & 85 & 85 \\
\hline
\end{tabular}




\section{Energy analysis}

The energy analysis in this study evaluates the general energy performance of the five systems by analysing the energy input and output values and quantifying the energy flows in the life cycle phases from cradle to gate that includes the materials extraction, manufacturing, assembly and production of the whole systems and their components.

An estimation of EPBT for the systems was made by analysing the embodied energy in the manufacturing process of roof top systems. The energy produced by the systems was also calculated in this study.

\section{- Embodied energy}

Best practices and improved manufacturing processes result in lower embo- died energy requirements [6]. Lately, the energy requirements for manufacturing new PV systems have notably decreased and it is expected to be further decreased in the near future [8]. Particularly with the emerging of new manufacturing technologies that are prospected to improve the environmental performance of PV technologies [2]

The manufacturing process can be the main contributor to the embodied energy, particularly for mono-si and poly-si where the crystallisation and purification processes require high energy allocation due to the very high temperature at which they are conducted [6].

In order to develop a comparative analysis, it is important to consider the energy flows during the lifecycle phases. Table (2) presents the embodied energy consumption for FPC adopted from [12].

Table 2: Embodied energy in FPC

\section{Direct energy consunption}

Primary ellergy (MJ)

\begin{tabular}{lc}
\hline Electricity & \\
\hline Absorbing collector & 191.0 \\
\hline Water tank & 324.0 \\
\hline Support & 27.6 \\
\hline Total & 542.6 \\
\hline Electricity & \\
\hline Installation & 1.8 \\
\hline Total & 1.8 \\
\hline Diesel for transport & 346.5 \\
\hline Materials & 172.7 \\
\hline Installation & 155.1 \\
\hline Maintenance & 23.6
\end{tabular}




\begin{tabular}{|c|c|c|c|}
\hline нияндинани & & 102.1 & \\
\hline Disposal & \multicolumn{2}{|r|}{23.6} & \\
\hline Total & \multicolumn{2}{|r|}{697.9} & \\
\hline \multicolumn{4}{|c|}{ Embodied energy of materials } \\
\hline & Fuel (MJ) & Feedstock (MJ) & Total \\
\hline Collector & 3297.1 & 215.3 & 3512.5 \\
\hline Water tank & 3641.0 & 485.9 & 4126.9 \\
\hline Support & 1066.4 & - & 1066.4 \\
\hline Other & 64.9 & 41.7 & 106.7 \\
\hline Packaging & 147.0 & 141.9 & 289.0 \\
\hline Maintenance & 544.1 & 627.2 & 1171.3 \\
\hline Total & 8760.6 & 1512.1 & 10272.7 \\
\hline \multicolumn{4}{|c|}{ Global energy consumption } \\
\hline
\end{tabular}

Considering the system boundary "from cradle to gate" that was considered for this study, the embodied energy in the FPC was found to be $4392 \mathrm{MJ} / \mathrm{m} 2$.
Table (3) presents the energy requirement of PV modules along with the BOS components that can contribute to a large part of the total embodied energy [10].

Table 3: Embodied energy for PV systems

\begin{tabular}{|c|c|c|c|}
\hline \multirow[t]{2}{*}{ Module Mono-Si/Poly-Si } & & & \multirow[t]{2}{*}{ Source } \\
\hline & Mono-Si & Poly-Si & \\
\hline MG-Si production $\left(\mathrm{MJ} / \mathrm{m}^{2}\right)$ & 450 & 450 & {$[6] 25$} \\
\hline Silicon purification $\left(\mathrm{MJ} / \mathrm{m}^{2}\right)$ & 1800 & 1800 & $\lceil 6\rceil$ \\
\hline Crystallisation \& contouring $\left(\mathrm{MJ} / \mathrm{m}^{2}\right)$ & 2300 & 750 & [6] \\
\hline Wafering $\left(\mathrm{MJ} / \mathrm{m}^{2}\right)$ & 250 & 250 & [6] \\
\hline Cell processing $\left(\mathrm{MJ} / \mathrm{m}^{2}\right)$ & 550 & 600 & [6] \\
\hline Module assembly $\left(\mathrm{MJ} / \mathrm{m}^{2}\right)$ & 350 & 350 & [6] \\
\hline Frame $\left(\mathrm{MJ} / \mathrm{m}^{2}\right)$ & 300 & 300 & \\
\hline Total module $\left(\mathrm{MJ} / \mathrm{m}^{2}\right)$ & 6000 & 4500 & \\
\hline \multicolumn{4}{|l|}{ Module a-Si } \\
\hline Module production $\left(\mathrm{MJ} / \mathrm{m}^{2}\right)$ & & 1200 & $36[2]$ \\
\hline \multicolumn{4}{|l|}{ Module CdTe } \\
\hline Module production $\left(\mathrm{MJ} / \mathrm{m}^{2}\right)$ & & 811 & $41[2]$ \\
\hline \multicolumn{4}{|l|}{ BOS 46 FROM [2] } \\
\hline Array support and cabling $\left(\mathrm{MJ} / \mathrm{m}^{2}\right)$ & & 70 & \\
\hline Inverter $\left(\mathrm{MJ}_{\mathrm{n}} / \mathrm{Kw}_{\mathrm{p}}\right)$ & & 1300 & \\
\hline
\end{tabular}

The final considered values of em- the system boundary "from cradle to gate". bodied energy for the PV systems were Average values between the highest and obtained from the literature according to lowest were utilised for the comparisons in 
table (4). A big variation was found in the examined dataset from the literature that can be attributed to the lack of transparen- cy or most likely to the considered aspect of LCA modelling [10].

Table 4: Embodied energy for the solar systems

\begin{tabular}{lccccc}
\hline System type & FPC & Mono-Si & Poly-Si & a-Si & CdTe \\
\hline Embodied energy $\left(\mathbf{M J} / \mathbf{m}^{2}\right)$ & 4392 & 3532 & 2876 & 1200 & 811 \\
\hline Source & {$[12]$} & {$[6]$} & {$[6]$} & $36[2]$ & $41[2]$ \\
\hline
\end{tabular}

- Energy output

It is the amount of energy produced by the solar system per year Eout .

Solar radiation is a determinant factor in estimating the energy produced by the systems during their life cycle functionality. Thus, the energy output of the solar systems is site dependent and variable [7].
Using the Portuguese simulation Software SCE.ER and referring to the context of Guimarães which is found that it receives an irradiation of $1450 \mathrm{kWh} /$ $\mathrm{m} 2 / y r$, the energy output from the systems are presented in table (5). Both thermal and electrical outputs from the solar systems were considered in their primary energy values.

Table 5: Energy output of the systems

\begin{tabular}{lccccc}
\hline System type & FPC & Mono-Si & Poly-Si & a-Si & CdTe \\
\hline Enelgy output $\left(\mathbf{M J} / \mathbf{m}^{2}\right)$ & 2632 & 879 & 782 & 407 & 587 \\
\hline
\end{tabular}

\section{Energy pay-back time}

The energy pay-back time is defined as the time required for an energy system to generate the same quantity of the energy consumed by the system and its components during its lifecycle steps. Values of energy input and output should be converted to their primary energy equivalents.
EPBT of solar systems is dependent on the geographical location. Systems in northern Europe need more time than the ones in southern Europe to reach the breakeven time to balance the embedded energy. Other parameters such as efficiency, performance ration, insolation and embodied energy also affect the value of EPBT [10].

The EPBT is calculated as presented in the following equation:

$$
E P B T=\frac{E_{\text {input }}}{E_{\text {output }}}
$$

Where $\mathrm{E}_{\text {input }}$ is the embodied primary energy during the systems life cycles including the BOS components for PV systems.

$\mathrm{E}_{\text {output }}$ is the annual generated energy by the systems considering the losses. 
By applying the previous equation, the EPBT for the systems were calculated as table (6) presents.

\begin{tabular}{lcccccc} 
*able 6: EPBT of the systems & & & & & \\
\hline System type & FPC & Mono-Si & Poly-Si & a-Si & CdTe \\
\hline EPBT (years) & 1.7 & 4 & 3.7 & 3 & 1.4 \\
\hline
\end{tabular}

\section{Results and Discussion}

By analysing the energy requirements of the examined technologies for slantedroof mounted systems under $1450 \mathrm{kWh} /$ $\mathrm{m} 2 / \mathrm{yr}$ irradiation, the estimated EPBT values of the solar systems were varied from 1.4 to 4 years from lowest to highest ranking the systems as follows; CdTe, FPC, a-Si, Poly-Si and Mono-Si.

The results show a small difference between Mono-Si and Poly-Si EPBT values, however, although the energy requirements to produce Mono-Si is higher than Poly-Si, the conversion efficiency in Mono-Si is greater than Poly-Si. The thin film system of $\mathrm{CdTe}$ and the solar thermal collector FPC showed the lowest estimates of energy pay-back time with $1.4 \mathrm{yr}, 1.7 \mathrm{yr}$, respectively.

The study shows a higher variation in the embodied energy values of the systems, on the contrary, it shows a lower difference in efficiency and performance ratio for the PV systems, thereby, we can conclude that in order to better develop the energy performance, the future improvements should focus on the embodied energy reduction rather than the efficiency of the modules.

\section{Conclusion}

The resulted EPBT values are slightly different from the values existing in the literature, this can be attributed to the assumptions made in this study and the context in which was conducted for example the solar irradiation in the studied of southern Europe is usually set to $1700 \mathrm{kWh} / \mathrm{m} 2 / \mathrm{yr}$ whereas in the present study, the solar irradiation of Guimarães is lower with $1450 \mathrm{kWh} / \mathrm{m} 2 / \mathrm{yr}$ and this resulted in higher EPBT values.

Also, the system boundary is another important factor in obtaining variant results. In the present study the model "from cradle to grave" was considered due to the lack of information regarding the installation, transportation and end of life management process which play prominent role for the long term sustainability of this industry.

The estimations assert that the both PV systems and solar thermal collectors FPC are effectively beneficial and have large potential in reducing energy consumption. 


\section{Bibliography}

[1]A. Nishimura et al., "Life cycle assessment and evaluation of energy payback time on high-concentration photovoltaic power generation system," Appl. Energy, vol. 87, no. 9, pp. 2797-2807, Sep. 2010.

[2]J. Peng, L. Lu, and H. Yang, "Review on life cycle assessment of energy payback and greenhouse gas emission of solar photovoltaic systems," Renew. Sustain. Energy Rev., vol. 19, pp. 255-274, Mar. 2013.

[3]E. Carnevale, L. Lombardi, and L. Zanchi, "Life Cycle Assessment of solar energy systems: Comparison of photovoltaic and water thermal heater at domestic scale," Energy, vol. 77, pp. 434-446, Dec. 2014.

[4] S. M. Silva, R. Mateus, L. Marques, M. Ramos, and M. Almeida, "Contribution of the solar systems to the $\mathrm{nZEB}$ and ZEB design concept in Portugal - Energy, economics and environmental life cycle analysis," Sol. Energy Mater. Sol. Cells, vol. 156, pp. 5974, Nov. 2016.

[5] European commission, "A policy framework for climate and energy in the period from 2020 to 2030.," 2014.

[6]J. H. Wong, M. Royapoor, and C. W. Chan, "Review of life cycle analyses and embodied energy requirements of single-crystalline and multi-crystalline silicon photovoltaic systems," Renew. Sustain. Energy Rev., vol. 58, pp. 608-618, May 2016.
[7]I. Nawaz and G. N. Tiwari, "Embodied energy analysis of photovoltaic (PV) system based on macro- and micro-level," Energy Policy, vol. 34, no. 17, pp. 3144-3152, Nov. 2006.

[8]S. Zanoni and L. Mazzoldi, "Long Term Analysis of Energy Payback Time for PV Systems," in Advances in Production $\mathrm{Ma}$ nagement Systems. Sustainable Production and Service Supply Chains, vol. 414, V. Prabhu, M. Taisch, and D. Kiritsis, Eds. Berlin, Heidelberg: Springer Berlin Heidelberg, 2017, pp. 395-401.

[9]E. Sarah, "MAKING SOLAR PANELS GREENER,” ChemEngNews, 2011.

[10] K. P. Bhandari, J. M. Collier, R. J. Ellingson, and D. S. Apul, "Energy payback time (EPBT) and energy return on energy invested (EROI) of solar photovoltaic systems: A systematic review and meta-analysis," Renew. Sustain. Energy Rev., vol. 47, pp. 133-141, Jul. 2015.

[11] S. A. Kalogirou, "Environmental benefits of domestic solar energy systems," Energy Convers. Manag., vol. 45, no. 18-19, pp. 3075-3092, Nov. 2004.

[12] F. Ardente, G. Beccali, M. Cellura, and V. Lo Brano, "Life cycle assessment of a solar thermal collector," Renew. Energy, vol. 30, no. 7, pp. 1031-1054, Jun. 2005. 